\title{
Being a 'citizen' in the smart city: up and down the scaffold of smart citizen participation in Dublin, Ireland
}

\author{
Paolo Cardullo $\mathbb{1}$ - Rob Kitchin $\mathbb{D}$
}

Published online: 12 January 2018

(C) Springer Science+Business Media B.V., part of Springer Nature 2018

\begin{abstract}
Reacting to critiques that the smart city is overly technocratic and instrumental, companies and cities have reframed their initiatives as 'citizencentric'. However, what 'citizen-centric' means in practice is rarely articulated. We draw on and extend Sherry Arnstein's seminal work on participation in planning and renewal programmes to create the 'Scaffold of Smart Citizen Participation'-a conceptual tool to unpack the diverse ways in which the smart city frames citizens. We use this scaffold to measure smart citizen inclusion, participation, and empowerment in smart city initiatives in Dublin, Ireland. Our analysis illustrates how most 'citizen-centric' smart city initiatives are rooted in stewardship, civic paternalism, and a neoliberal conception of citizenship that prioritizes consumption choice and individual autonomy within a framework of state and corporate defined constraints that prioritize market-led solutions to urban issues, rather than being grounded in civil, social and political rights and the common good. We conclude that significant normative work is required to rethink 'smart citizens' and 'smart citizenship' and to remake smart cities if they are to truly become 'citizen-centric'.
\end{abstract}

P. Cardullo $\cdot$ R. Kitchin $(\bowtie)$

National Institute for Regional and Spatial Analysis,

National University of Ireland, Maynooth,

County Kildare, Ireland

e-mail: rob.kitchin@mu.ie
Keywords Smart city - Citizens - Participation · Engagement $\cdot$ Citizenship $\cdot$ Rights

\section{Introduction}

In the last few years many cities have created and implemented policies and programmes intended to transform them into a 'smart city'. To that end, city administrations, often partnering with companies, have adopted a variety of networked technologies to mediate the management of city services and regulate city life (e.g., city operating systems, urban control rooms, coordinated emergency management response systems, intelligent transport systems, smart grids, smart lighting, sensor-networks, etc.). These have been complemented by a number of initiatives and services produced and delivered by companies and civic organizations, such as mobile/locative media and the sharing economy (using digital platforms to connect distributed groups of people for more efficient use of goods, skills and other resources). However, the mission to produce smart cities has been critiqued for being overly technocratic and top-down in orientation, serving the interests of states and corporations more than they do those of citizens (Greenfield 2013; Kitchin 2014b). According to these critiques, smart city initiatives enact forms of algorithmic governance that control and discipline citizens, as well as being 
tools to produce and reinforce neoliberal logics of urban management and entrepreneurial urban development (Datta 2015; Greenfield 2013; Kitchin et al. 2017a; Sadowski and Pasquale 2015; Shelton et al. 2015; Vanolo 2016). In other words, smart city initiatives are said to be underpinned by a neoliberal conception of citizenship that favours consumption choice and individual autonomy within a framework of constraints that prioritize market-led solutions to urban issues, reinforced through practices of stewardship (for citizens) and civic paternalistism (deciding what is best for citizens) enacted by states and companies, rather than being grounded in civil, social and political rights and the common good (Clark and Shelton 2016; Gabrys 2014; McLaren and Agyeman 2015; Swyngedouw 2016).

In response to these critiques, the developers, promoters and deployers of smart city technologies and initiatives have sought to reposition them as being citizen- or community-centric. For example, in their marketing material, companies such as IBM and Cisco have declared that their solutions are now "citizenfocused". " Since 2011 the European Commission has branded its funding programmes for creating smart cities the 'European Innovation Partnership for Smart Cities and Communities' (EIP-SCC) ${ }^{2}$ with a dedicated "citizen-focus" cluster. Likewise, cities have branded their smart city programmes and initiatives as "citizen-focused" or "citizen engaged". However, such a re-formulation appears to be a re-branding exercise, Kitchin (2015) argues, designed to silence detractors or bring them into the fold while keeping the central mission of capital accumulation and technocratic governance intact. Citizenship in such formulations operates largely as an empty signifier, often calling for "citizen inclusion" or searching for the "missing citizen" but the underlying neoliberal ethos and mode of governmentality remains unchanged (Hill 2013; Sartori 2015). As such, despite the drive to create smart cities, to date there has been little critical conceptual scrutiny as to how citizens are imagined and engaged by different smart city technologies and the model of citizenship enacted within smart citiesalthough there are case studies and theoretical scrutiny

\footnotetext{
1 https://www.ibm.com/smarterplanet/us/en/smarter_cities/ overview/ http://www.cisco.com/c/en/us/solutions/industries/ smart-connected-communities.html.

${ }^{2}$ https://eu-smartcities.eu.
}

of citizen engagement in crowdsourcing (e.g., Gabrys 2014), in participatory planning (de Lange and de Waal 2013), in the device-enabled shift from user to consumer (Fuller 2017), or more broadly in terms of smart city schemes and strategies (Cowley et al. 2017; March and Ribera-Fumaz 2017; Vanolo 2016).

In this paper, we examine in detail the framing of, and the roles performed by, citizens in smart cities. We do so by considering smart city initiatives in Dublin, Ireland - drawing on extensive fieldwork in the cityto create an adapted version of Sherry Arnstein's (1969) ladder of participation, what we term "the scaffold of smart citizen participation". Then, we use this scaffold to revisit critically the extent to which smart city initiatives in the city are 'citizen-centric' in ways that constructively address technocratic critiques of the smart city—redistributing power, resources and control, or instead work to reproduce and reinforce forms of neoliberal citizenship and urban entrepreneurship.

Our field site, Dublin, is a city that promotes itself actively as a smart city through its Smart Dublin ${ }^{3}$ office (a unit shared between the four Dublin local authorities to coordinate and promote its smart city mission) and has rolled out a number of mainstreamed smart city initiatives, as well as acting as a testbed for many more in development (Coletta et al. 2017). Since the late 1980s, Ireland has embraced the tenets of neoliberalism, creating a political and economic model that blends American neoliberalism (minimal state, privatization of public services, public-private partnerships, developer/speculator-led planning, low corporate and individual taxation, light to no regulation, clientelism) with aspects of European social welfarism (developmental state, social partnership, welfare safety net, high indirect tax, EU directives and obligations) (Breathnach 2010; Kitchin et al. 2012). In turn, Dublin is considered a neoliberal city, adopting ideas of entrepreneurial planning in the 1990s, the creative city discourse in the 2000s, and smart city in the 2010s (MacLaran and Kelly 2014). In political economy terms, the city is thus similar to many European and American cities which have pursued neoliberal, entrepreneurial, competitive strategies, including a variety of smart city initiatives. Nonetheless, Smart Dublin promotes itself as "Open, Engaged,

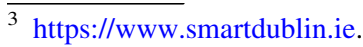


Connected", where 'engaged' relates to citizen engagement.

Our analysis draws from an archive of extensive fieldwork conducted between 2014 and 2016 as part of a large European-funded project. The fieldwork consisted of a combination of methods, such as a couple of hundred interviews with smart city actors and stakeholders, a number of detailed ethnographic case studies conducted by several team members, and attendance at dozens of industry, city authorities and civic meetings and events. In addition, one of the authors is one of only two external members of the Smart Dublin steering group, regularly attending monthly meetings. In building and using the scaffold, we adopted a hybrid methodology which was neither purely deductive nor inductive, but started with abduction and then combined elements of induction and deduction in an iterative process (see Kitchin 2014a; Wilson and Chaddha 2009). ${ }^{4}$ Abduction involves identifying an approach or conceptual frame that makes logical sense given what is already known about a phenomenon and is very commonly used in science, especially in the formulation of hypotheses (Miller 2010). Our starting point then was to consider a way of making sense of citizens within the smart city, drawing on our well of knowledge of the literature and existing conceptual frameworks. Arnstein's ladder-a popular conceptual frame for examining citizen participation in place-making and city governanceseemed to offer a useful heuristic to start to interrogate the framing and role of citizens in the smart city. Through critical reflection on how citizens were positioned in each initiative we then started to match smart city endeavours to the 'rungs' on Arnstein's ladder - to deductively test both the validity of the theoretical frame and the extent to which smart cities are citizen-focused. What became apparent was that while the ladder had utility, it also had some limitations. Using our case examples, we then began to iteratively reconstruct the ladder into a scaffold, reflecting on the roles played, the form and nature of citizen involvement, and underlying political discourse. In this sense, the scaffold was re-built inductively through the case study material. In the final

\footnotetext{
$\overline{4}$ This approach is now commonly practised in the big data age as data-driven science, where a combination of abduction and inductive data exploration is used to identify salient hypotheses for deductive testing (Miller 2010; Kitchin 2014a, b).
}

stage, we then used the scaffold as a heuristic to assess how citizens are conceived and positioned within Dublin's smart city initiatives, the diverse roles they play, and the extent to which initiatives are grounded in and reproduce the discursive and material practices of the "actually existing" neoliberal smart city (Shelton et al. 2015). Our proposition is that the scaffold can be used as a heuristic tool by scholars and stakeholders to critically evaluate the citizen-focused nature of smart technologies and projects beyond the rhetoric offered by the smart city discourse in other cities.

\section{The scaffold of smart citizen participation}

In 1969, Sherry Arnstein published a highly influential paper on the ways in which citizens are involved in the planning process and regeneration programmes. Her thesis was that planning is a top-down, technocratic exercise that takes little account of citizens' views or desires. She formulated a conceptual ladder with eight rungs "corresponding to the extent of citizens' power in determining the end product" (1969, p. 217 see Table 1). On the lower rungs we find forms of 'nonparticipation' ('manipulation' and 'therapy'), which are designed to direct and educate people in a topdown, formal manner, steering and controlling them. She then defines 'tokenism' ('informing', 'consultation', and 'placation') as a form of participation in which people have voice and some degree of autonomy, though they are rarely able to change directly the status quo of decisions and plans already taken elsewhere. The final three rungs concern 'citizen power': 'partnership', in which citizens can take an active participative role and share decision-making

Table 1 Arnstein's (1969) ladder of citizen participation in planning

Form and level of participation

Citizen power

Citizen control

Delegated power Partnership

Tokenism

Placation

Consultation

Informing

Non-participation

Therapy

Manipulation 
with dominant power-holders; 'delegated power', in which citizens are full actors and have a dominant decision-making role; and, 'citizen control', where "have-not citizens obtain full managerial power" (Arnstein 1969, 217).

In Arnstein's formulation, the quality and depth of citizen participation in planning is rooted in access to power. Although she never defines power, Arnstein maintains the control of power has significant implications to the socio-economic advancement of "havenots" and thus embodies the potential to transform "nobodies" into "somebodies" (1969, p. 217). Participation is linked to power to the extent it can induce "significant social reform", affecting the outcome of a process and eventually redistributing "the benefits of affluent society", rather than being only an "empty ritual” (p. 216). In other words, for Arnstein, participation and power can work together by reflecting an ideal of society that is more equal and just with respect to plan- and decision-making.

Since its publication, the ladder has attracted numerous critiques. Some scholars suggest that citizens' empowerment and participation might not be the desired goal for a society at any given time (Collins and Ison 2009), and note that just because citizens have control of a service does not mean it will be any more inclusive. Others seek to reclaim the role of 'the expert' in the decision-making process, whom with their domain-level expertise act on behalf of citizens (Hart 2008; Tritter and McCallum 2006). They maintain using domain-level experts-bureaucrats, technocrats, specialist workers-creates efficiencies and utilizes accreted knowledge to tackle issues that citizens may have little experience or knowledge of. Other scholars ask whether ladder-type schematics are the most appropriate way to structure and discuss the complexity and the multiplicity that participation entails, arguing they create an overly linear and evolutionary analysis, with forms of participation ordered in a way that demarcate their relative value and utility (Carpentier 2016; Wilcox 1994).

Despite critique, the popularity of Arnstein's ladder endures due to its heuristic utility to reveal the extent to which citizens are involved in formulating and participating in how services are conceived and delivered, and to expose the underlying political and citizenship discourses at work. However, after trying to fit Dublin's smart city initiatives to Arnstein's rungs, it is evident that Arnstein's formulation needs to be reworked in order to more fully account for the type, role, function, political discourse/framing, and modality of citizen participation in the neoliberal, entrepreneurial city. Thus, we have reworked Arnstein's ladder using its original framework but broadening it to provide a wider conceptual scaffolding (see Table 2).

Our initial reworking of the ladder was to add a ninth rung to the level of participation column: 'choice'. As we detail below with respect to our case study, this is to recognize that in the almost 50 years since Arnstein was writing states have embraced neoliberalism, with city services and infrastructures being increasingly marketized (treating citizens as customers) and privatized (corporations own key city assets and performing many key roles) (Brenner and Theodore 2002). As noted by a number of commentators (e.g., Larner 2003; Brenner et al. 2010) there are varieties of neoliberalism, shaped by national and local political economies, political ideology, state policies, institutional cultures, market practices, legal frameworks, public sentiment, etc., that variously inflect localised deployments of smart cities (Kitchin et al. 2017b). Nonetheless, a prime way in which a citizen interacts with the smart city is as a 'consumer', selecting which services to acquire from the marketplace of providers - or, in the case of free-to-use apps, swap personal data for. The second role citizen performs at this level is that of 'resident' with those who can afford the purchase/rent price able to choose to live in a 'smart building' or 'smart district', spaces that are often exclusive, gated communities. Consumerism in the smart city is 'citizen-centric' in as far as it seeks to provide a selection of information and services from a range of entities that fulfil a need. We have therefore slotted it into our scaffold between 'Non-Participation' and 'Tokenism'.

Our main alterations have been to add a number of related columns, some categories of which span Arnstein's rungs - hence, our use of scaffold rather than ladder. The first column added relates to the role expected of/adopted by citizens with respect to smart city initiatives: by systematically analysing a series of cases in Dublin and elsewhere, we have identified sixteen citizen roles that shift from passive and lacking control to active and responsible. The second column added concerns the form of citizen involvement enacted by citizens and the nature of their engagement, varying from forms of coercion through to visioning 
Table 2 Scaffold of smart citizen participation

\begin{tabular}{|c|c|c|c|c|c|c|}
\hline \multicolumn{2}{|c|}{$\begin{array}{l}\text { Form and Level of } \\
\text { Participation }\end{array}$} & Role & $\begin{array}{c}\text { Citizen } \\
\text { Involvement }\end{array}$ & $\begin{array}{l}\text { Political } \\
\text { discourse/ } \\
\text { framing }\end{array}$ & Modality & Dublin Examples \\
\hline \multirow{3}{*}{ Citizen Power } & Citizen Control & $\begin{array}{l}\text { Leader, } \\
\text { Member }\end{array}$ & \multirow{2}{*}{$\begin{array}{c}\text { Ideas, Vision, } \\
\text { Leadership, } \\
\text { Ownership, } \\
\text { Create }\end{array}$} & \multirow{2}{*}{$\begin{array}{l}\text { Rights, } \\
\text { Social/Political } \\
\text { Citizenship, } \\
\text { Commons }\end{array}$} & \multirow{3}{*}{$\begin{array}{l}\text { Inclusive, } \\
\text { Bottom-up, } \\
\text { Collective, } \\
\text { Autonomy, } \\
\text { Experimental }\end{array}$} & $\begin{array}{l}\text { Code for Ireland, } \\
\text { Tog }\end{array}$ \\
\hline & $\begin{array}{l}\text { Delegated } \\
\text { Power }\end{array}$ & $\begin{array}{l}\text { Decision-maker, } \\
\text { Maker }\end{array}$ & & & & Civic Hacking, \\
\hline & Partnership & Co-creator & $\begin{array}{l}\text { Negotiate, } \\
\text { Produce }\end{array}$ & \multirow[b]{2}{*}{$\begin{array}{l}\text { Participation, } \\
\text { Co-creation }\end{array}$} & & $\begin{array}{l}\text { Hackathons, Living } \\
\text { Labs, Dublin Beta }\end{array}$ \\
\hline \multirow{3}{*}{ Tokenism } & Placation & Proposer & Suggest & & \multirow{7}{*}{$\begin{array}{l}\text { Top-down, } \\
\text { Civic } \\
\text { Paternalism, } \\
\text { Stewardship, } \\
\text { Bound-to- } \\
\text { succeed }\end{array}$} & $\begin{array}{l}\text { Fix-Your-Street, } \\
\text { Smart Dublin } \\
\text { Advisory Network }\end{array}$ \\
\hline & Consultation & $\begin{array}{l}\text { Participant, } \\
\text { Tester, } \\
\text { Player }\end{array}$ & Feedback & \multirow[t]{2}{*}{ Civic Engagement } & & $\begin{array}{l}\text { CIVIQ, Smart } \\
\text { Stadium }\end{array}$ \\
\hline & Information & Recipient & \multirow{3}{*}{$\begin{array}{l}\text { Browse, } \\
\text { Consume, } \\
\text { Act }\end{array}$} & & & $\begin{array}{l}\text { Dublinked, Dublin } \\
\text { Dashboard, RTPI }\end{array}$ \\
\hline \multirow{2}{*}{ Consumerism } & \multirow[t]{2}{*}{ Choice } & \multirow{2}{*}{$\begin{array}{l}\text { Resident, } \\
\text { Consumer }\end{array}$} & & \multirow{2}{*}{$\begin{array}{l}\text { Capitalism, } \\
\text { Market }\end{array}$} & & $\begin{array}{l}\text { Smart building/ } \\
\text { Smart district }\end{array}$ \\
\hline & & & & & & $\begin{array}{c}\text { Smart meters, } \\
\text { Mobile/locative } \\
\text { media }\end{array}$ \\
\hline \multirow{2}{*}{$\begin{array}{c}\text { Non- } \\
\text { Participation }\end{array}$} & Therapy & \multirow{2}{*}{$\begin{array}{c}\text { Patient, Learner, } \\
\text { User, Product, } \\
\text { Data-point }\end{array}$} & \multirow{2}{*}{$\begin{array}{l}\text { Steered, } \\
\text { Nudged, } \\
\text { Controlled }\end{array}$} & \multirow{2}{*}{$\begin{array}{l}\text { Stewardship, } \\
\text { Technocracy, } \\
\text { Paternalism }\end{array}$} & & $\begin{array}{l}\text { Dublin Bikes, } \\
\text { Smart Dublin }\end{array}$ \\
\hline & Manipulation & & & & & Traffic control \\
\hline
\end{tabular}

and steering initiatives. The third additional column refers to the political discourse used to justify and drive the various forms, levels, roles, and involvement of citizens. The final additional column is the modality in broad terms as to how citizens are positioned vis-àvis the smart city. In the lower half of the scaffold initiatives are most often top-down in conception, being devised by city administrations or corporations, and are broadly underpinned by notions of stewardship and civic paternalism (see Clark and Shelton 2016). These projects are 'bound-to-succeed' in the sense that there is an expectation that these initiatives will deliver on their promise to produce a 'smarter' city and not waste taxpayers' money or shareholder investment. In contrast, in the top half of the table, initiatives are more bottom-up in conception, being devised in part or in whole by various citizens or groups, and are more collective in how they operate. These initiatives are more experimental in nature and it is understood that they might fail to create a long-term, sustainable outcome.

\section{The forms and levels of citizen participation in Dublin}

\section{Non-participation}

'Non-participation' occurs when citizens are nudged and steered towards specific sets of behaviour, practice, and conduct. This can be the case for interventions that require very little input from citizens other than to use or experience an algorithmically-mediated service for the purposes of governmentality, such as the production of big data that "intensifies the extent and frequency of monitoring and shifts the governmental logic from surveillance and discipline to capture and control" (Kitchin et al. 2017b, p. 3). Here, citizens become subject to a modulation of their actions through software-mediated systems designed to produce particular regulatory outcomes that actively shapes behaviour.

For example, in the case of Dublin, traffic flow is regulated by the Traffic Management and Incident 
Center (TMIC) and its use of SCATS (Sydney Coordinated Adaptive Traffic System) (McCann 2014). SCATS is an automated and adaptive system whose primary role is to manage the dynamic timing of signal cycles and phases at road junctions in order to ensure the optimal flow. The system automatically calibrates the cycles and phases dependent on a set of programmed rules and the flow, speed, and density of traffic for each lane of traffic in previous cycles and phases (as measured in real-time by a network of 800 inductive loop sensors) (Coletta and Kitchin 2017; McCann 2014). In addition, the TMIC has access to 380 CCTV cameras, a small number of traffic camera, a mobile network of c.1000 bus transponders, phone calls and messages by the public to radio stations and operators, and social media posts (Coletta and Kitchin 2016). Citizens and their vehicles become data-points in a fluctuating system, with the data generated used to calibrate the system and traffic flow. Information from the system is also pushed out to citizens via apps, the Dublin Dashboard, ${ }^{5}$ real-time passenger information at bus-stops, and on-street signs stating numbers of vacant spaces in car parks, which nudge decisionmaking with respect to choice of route and parking.

For Gabrys (2014) in systems wherein citizens and their technologies (e.g., vehicles, smartphones) act as sensors they are reduced to data-points that provide information with often little access to, and no political capital to act upon, those data. She further suggests that strategies of monitoring, gaining efficiency using sensors and the programming of environments generate ambividuals: "ambient and malleable urban operators that are expressions of computer environments" (Gabrys 2014, p. 42). The outcome is here double: on the one hand, the participant provides data necessary to the success of the project, being co-opted in neoliberal discourses of efficiency and environmental sustainability; on the other, the citizen is steered and controlled by way of nudging, that is, gently persuaded of how to conduct a way of life contained within optimal or ideal targets-for example, around environmentally friendly use of resources or care of own body (here, a citizen is also a 'patient'). In addition, these data, along with those generated from other sources (such as using locative media or a city service) can be mined for insights, traded with and between

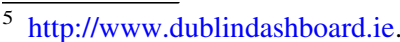

data brokers, and conjoined with other data for the purposes of social sorting, predictive profiling, micromarketing, anticipatory governance and city planning (Kitchin 2014b). In other words, citizens using algorithmically-mediated services can become data products, raising a series of ethical questions concerning over-extended and intrusive surveillance as well as privacy and predictive privacy harms (Kitchin 2016).

Personal views can also be reshaped through education and social learning. Driving and facilitating the smart city movement is a broad advocacy coalition of stakeholders (e.g., private industry, lobby groups, philanthropists, politicians, civic tech bodies) and urban technocrats (e.g., chief innovation officers, project managers, consultants, engineers, and academics) that work across scales from the global to local to promote and enculturate the ideas and ideals of using digital technologies to manage cities and solve urban issues (Kitchin et al. 2017a). In the case of Dublin, 'Smart Dublin' is a part of this coalition. A shared initiative of the four city authorities it seeks to coordinate and promote smart city initiatives, seeking to influence city worker attitudes to the notion of the smart city through social learning in the form of workshops, sponsoring pre-procurement challenges, and fostering collaborative projects between local authority departments and companies. With respect to citizens, it communicates its work through its website and creates social learning through organizing/sponsoring hackathons. ${ }^{6}$ In this way, workers and citizens are educated to the logic of a smart city.

Non-participation in the smart city is underpinned by a strong technocratic impulse (aspects of the city can be treated as technical problems that can be addressed by technical solutions), and notions of stewardship and civic paternalism, where citizens are little if ever consulted in how initiatives are formulated or deployed. Their participation is thus narrowly framed in a very instrumental way. Moreover, accountability by service providers is sometimes lacking because smart city initiatives are often delivered by what Swyngedouw (2005, p. 1992) terms "beyond-the-state" or "hybrid configurations"; that is, the recent proliferation of flexible and decentered models of urban governance. The proliferation of new

\footnotetext{
${ }^{6}$ A gathering where programmers collaboratively code in an extreme manner over a short period of time, a few days or over a weekend.
} 
administrative units, quangos, public-private agencies and 'experts' (middle management, external contractors, data analysts, chief innovation officers), and the splintering of infrastructural provision, further dissipate a transparent and democratic process. Indeed, many smart city initiatives and cooperative projects with companies are implemented by agencies with little, if any, political oversight.

\section{Consumerism}

According to Fuller (2017), the shift from a user of technologies to consumer is aided by the transformation in the design and functioning of computational devices, from personal computers to cloud- and platform-based economies on the Internet. There are now thousands of app-driven services designed to transform city living. The vast majority of these are owned and operated by private corporations who utilise digital technologies to deliver new services based on a combination of location, real-timing, identity and algorithmic profiling. These services are often disruptive, radically altering established orders. For example, a certain version of the sharing economy is transforming the taxi (e.g., MyTaxi) and accommodation (e.g., Airbnb) industries, as well as employment practices (e.g., the gig economy), including in Dublin (MacLaran and Kelly 2014).

In addition, people can embrace a 'smart lifestyle' by becoming a resident in a smart building or district. Such buildings and areas are often served by multiple smart city technologies designed to enhance the lives of residents through improved security, energy and waste services, and transportation and parking options. In Dublin, the 'Silicon Docks' area of the city-a special development zone being regenerated through a mix of high-end offices and residential apartmentshas recently been designated a 'smart district' (Heaphy and Pétercsák 2016). Home to the European headquarters of companies such as Google, Facebook and Linkedin, the area has become a testbed for new smart technologies and acts as means to attract additional inward investment (especially from urban Internet of Things companies). Much of the space created is privately owned and managed rather than being public space, with such developments operating for the benefit of their owners and counter to that of an urban commons. A 'smart citizen' in such developments is a high-income consumer seeking an exclusive property investment with the latest technological trimmings.
In such a framing, citizens are afforded a choice of services/products, but the choice is often quite constrained in two ways. First, the systems on offer are largely pre-determined in nature, with the consumer reduced to tinkering with parameters rather than being able to radically reconfigure the service. Second, the choice between services is often limited to a couple of providers who have quickly gained monopoly positions, or are built to work on platforms that are monopolies. As urban services traditionally delivered by city administrations are being privatized or delivered through service contracts with private corporations or public-private partnerships, citizens are recast from citizens with rights and entitlements, who receive a service in return for taxation, to consumers who select from a marketplace of options. In a deregulated energy marketplace, consumers can choose an electricity supplier who competes for business by offering different tariffs and services. In the case of a residence fitted with a smart meter they can also monitor their consumption using an app and can choose when to use electricity to minimize cost (e.g., timing a washing machine to operate when unit costs are low). In general, services are designed and operated with limited involvement by citizens other than as users. If citizens are involved, it is usually to provide feedback during requirement's analysis in the design phase or act as beta-testers of products in the production phase. Here, feedback is used to tweak already conceived designs, rather than to form the bedrock for design thinking. Like 'non-participation', 'consumerism' is then undergirded by a strong technocratic framing. It also has strong notions of stewardship and paternalism, with the market largely determining what is in the best interests of citizens.

\section{Tokenism}

'Tokenism' concerns various degrees of public engagement and citizen voice. In its lower form, it consists of 'informing' where citizens can access open data that, on the one hand, inform them as to what is happening in the city, and on the other, can be repurposed to form the input for citizen-created apps. In Dublin, Dublinked ${ }^{7}$ — an initiative co-owned by the four local authorities-is the city's open data store,

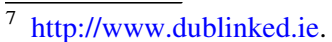


sharing a mix of administrative and operational data, including some real-time datasets related to transport and environment. Much of these data, along with statistical data and administrative data published by other government agencies, are made available to the public through the Dublin Dashboard as interactive maps, graphs and apps. Such information can be used to shape decision-making and also be used to create transparency and accountability with regards to the actions and decisions of administrations (a key argument of the open data movement). However, while 'informing' can be highly useful, it is often unidirectional, with limited or no channel for feedback provided. Moreover, information is often provided after key planning and decision-making processes have occurred, leaving little or no room for change.

In its higher forms, tokenism constitutes 'consultation' and 'placation'. In 'consultation' citizens are requested to provide feedback representing their views through various forms of social media and online tools for citizen consultation (de Waal 2014; Seltzer and Mahmoudi 2013). In the Dublin case, an example would be the use of CIVIQ, an online consultation tool that enables citizens to comment on and discuss draft county development plans. ${ }^{8}$ Another form of consultation is through user-testing and feedback, which can often occur without citizens being aware that it is occurring. For example, in the Smart Stadium ${ }^{9}$ initiative Internet of Things prototypes are being trialled for monitoring crowd behaviour, service performance, and stadium management. Here, feedback is given passively through mere presence and action. In 'placation' rather than simply feedback on proposals, citizens are able to suggest alternatives and additions to those proposed. In Dublin, an example is Fix-Your-Street, ${ }^{10}$ wherein citizens can use an online tool to report the location of issues that need to be addressed (such as potholes, graffiti, broken streetlights, illegal dumping), thus suggesting an alternative work program for city workers. Smart Dublin also has appointed an advisory network of forty key stakeholders drawn from government, companies, universities and civil society that meets twice a year to offer

\footnotetext{
8 http://www.civiq.eu.

9 At Croke Park Stadium, an 80,000 seater venue owned and operated by the Gaelic Athletics Association. https://dcu.asu. edu/content/smart-stadium.

10 http://fixyourstreet.ie.
}

constructive feedback on Dublin's smart city initiatives.

'Consultation' and 'placation' can work to keep civic paternalism in check by challenging the aspirations and assertions of 'experts' and politicians. Nonetheless, Arnstein argues that citizens are asked to contribute to a set of initiatives which are already largely predetermined in their scope and how they will operate. Indeed, in the time-line we have encountered in our investigation of publicly funded smart city initiatives, citizen consultation often occurs after the approval of the detailed project objectives. In this sense, citizens are enabled to partially re-arrange the deckchairs on a ship's deck, but not to determine how the ship is run or its general course. In turn, city administrators are able to claim they involved citizens in their planning and decisions, but questions remain as to whom has the real decision-making power and how a proposed change is implemented. As Arnstein (1969, p. 217) notes, in tokenism "there is no follow through, no 'muscle', hence no assurance of changing the status quo".

In addition, 'consultation' and 'placation' suffer from the same issues that plague crowdsourcing initiatives in general: a bias towards the views of well-educated, technologically-literate participants in the digital public sphere (Crutcher and Zook 2009); a difficulty in sustaining a productive crowd long-term; and how to document degrees of validity, reliability and trustworthiness of the data generated (Dodge and Kitchin 2013). In this sense, although smart technologies seek to promote engagement, they might deepen structural barriers to socio-political participation related to education, class, gender, age and ethnicity. Moreover, the crowdsourcing process involves the donation of free labour by citizens in the production of new markets for consultation services, wherein consultation online platforms gain authored content (feedback), plus subsidiary authored information such as comments, tags, ratings, and cross-linking URLs that constitute valuable meta-content, which can be packaged and traded to third parties (Dodge and Kitchin 2013). A potential by-product of citizen engagement then is citizens and their views sliding down the scaffold to 'product'. For Arnstein, the solution to these tokenistic forms of participation was what she termed 'citizen power'. 


\section{Citizen power}

At the top of Arnstein's ladder are what she argued were more rewarding and representative forms of civic participation in which citizens have "increasing degrees of decision-making clout" (1969, p. 217). In 'partnership', planning and decision-making is shared, with agreed ground rules and mechanisms for moving projects forward and resolving impasses. 'Delegated power' occurs when citizens gain the dominant decision-making authority and genuine specified powers within a co-shared initiative. 'Citizen control' happens when citizens are fully in charge of the policy and managerial aspects of a program or institution and "can negotiate the conditions under which 'outsiders' may change them" (1969, p. 223).

In Dublin, it is difficult to identify an example of 'partnership' or 'delegated power' where initiatives are co-owned and co-created, and citizens share or have the dominant decision-making authority. Usually, examples are drawn from community development initiatives that are undertaken through a partnership between a community organization and the state, but such initiatives have not yet been created with regards to the smart city. Where co-creation does occur it is usually through short-term hackathons or civic hacking/living lab projects. There have been a number of such hackathons sponsored by the Dublin local authorities, along with corporate partners such as IBM and Intel, with respect to using the city's open data and producing smart city applications. While citizens who attend are free to produce whatever application they desire, the event is very much owned and run by the sponsors, who frame the event aims and provide space, mentors and guidance (Perng, Kitchin, and Mac Donncha 2017). In the Dublin case, a number of prototypes have been further developed post-event into commercial enterprises, such as Building Eye ${ }^{11}$ and Parkya. ${ }^{12}$ From this perspective, hackathons are a means to kindle and maintain business-led urban development and entrepreneurial urban governance (Perng et al. 2017), rather than producing citizen- or community-led smart city solutions.

In Dublin and elsewhere, there have recently been a number of Living Labs initiatives that adopt Lo-Fi

\footnotetext{
$\overline{11} \mathrm{https}: / / \mathrm{www} \cdot$ buildingeye.com.

12 https://parkya.com.
}

technologies, such as sensors for the monitoring of pollution. These initiatives typically work with a community of interest and are usually university- or industry-led. An example of a local authority-led initiative was Dublin Beta, which closed in early 2017. For a handful of years it trialled street-based pop-up initiatives working with local citizens, though most were low- or no-digital tech in nature (such as pop-up parks and secure bike sheds in parking bays) (Perng 2016). While such initiatives do involve citizens, the form and level of participation is often circumscribed. In addition, in projects led by one or a handful individuals initiatives are often hamstrung by decision-making processes being dominated by a "benevolent dictator" (Ljungberg 2000). In the Dublin Beta case, the project was led by a single Dublin City Council employee who drove the entire initiative. There are also concerns as to the extent to which Living Labs using formerly vacant space, or being deployed in regeneration programmes, act as gateways for gentrification (Cardullo et al. 2017).

There are, however, a handful of examples of 'citizen control' in Dublin. These include Code for Ireland $^{13}$ (an initiative owned and run by citizens to produce civic apps) and $\operatorname{Tog}^{14}$ (a community maker initiative). Citizens decide on the projects to be pursued and undertake the required development and implementation work. Unlike hackathons, the work usually unfolds over months, with team members meeting weekly or monthly to advance a project. Many of these projects are full of frictions and negotiation, with teams rarely staying stable and the outcome a compromise and gerry-rigged solution (Perng and Kitchin 2018).

While Arnstein views 'citizen power' as the pinnacle for creating cities that reflect the desires and aspirations of citizens, our discussion has illustrated how in practice bottom-up, inclusive, and empowering citizen involvement in key decisionmaking about cities is difficult to achieve. In part this is because there has been little sustained grassroots attempts to create community-led smart city initiatives, with communities tending to organize their activities and activism around addressing social and environmental issues through political and policy

\footnotetext{
$\overline{13}$ http://codeforireland.com.

${ }^{14}$ https://www.tog.ie.
} 
solutions rather than technological ones. In part, it is because the imperative for creating a smart city is being driven by a neoliberal ideology and corporate interests that dominate the landscape and circumscribe a particular role for citizens which is highly instrumental.

\section{Being a 'smart citizen' in the neoliberal smart city}

Our aim in this paper has been to unpack how citizens are framed within smart city initiatives and to examine the extent to which so-called "citizen-centric" initiatives offer an alternative to, or simply reproduce, the actually existing neoliberal smart city. Our contribution has been threefold. First, we have unpacked in detail how citizens are framed within 'citizen-centric' smart city initiatives, dissecting citizens into the myriad of social and legal positions they occupy in relation to networked and algorithm-led technologies implemented in cities. As our field site of Dublin makes clear there are numerous roles citizens play in the smart city and they can experience, at the same time, different forms of empowerment and participation. In so doing, we have constructed a much fuller typology of citizen roles, the form and nature of citizen involvement, and underlying political discourse, than previously documented.

Second, we have developed a heuristic tool-the scaffold of smart citizen participation-to compare and evaluate different projects from the perspective of 'the citizen'. The scaffold is a map of smart city inclusion and participation through which scholars and stakeholders can better understand who is involved and in what capacity in any existing and forthcoming smart city initiatives, beyond the powerful rhetoric of the smart city discourse. Rather than being exhaustive, the scaffold provides the basis for the formulation of new avenues of enquiry - for example, with regards to comparative analysis of different institutional arrangements and scales in the delivery of smart city projects, to the time-line through which projects are prepared, funded, and institutionalized, and to the actual existing spaces for feedback and adjustments within such projects. As way of illustration we used the scaffold to assess the 'citizen-centric' nature of smart city initiatives of Dublin, Ireland.

Third, the paper advances the framework of fragmented citizenship in advanced capitalism (e.g., Isin
2000; Ong 2006), adapting it to the existing and imagined smart city. In fact, it shows the instrumentality of the neoliberal ideals of 'citizen-centric' smart city approaches with the slipping away of citizen as a political subject holding a set of rights and entitlements (although at different times and in different spaces) to much weaker socio-economic and legal positions. With the exception of some 'citizen power' initiatives, all levels of the scaffold are consistent with neoliberal citizenship and its emphasis on personal autonomy and consumer choice, with individuals performing certain roles and taking responsibility for their own life chances (entrepreneurial self), and with the marketization and privatization of services and infrastructures (retreat of the state and austerity policy). While citizen participation is potentially diverse, it is most often framed in a post-political way that provides feedback, negotiation, participation and creation, but within an instrumental rather than normative or political frame. In other words, citizens are encouraged to help provide solutions to practical issues-such as producing an app, or feeding back on a development plan, or to perform certain roles/responsibilities-but not to challenge or replace the fundamental political rationalities shaping an issue or plan. Instead, most citizens are "empowered" in the smart city by technologies that treat them as consumers or testers, or people to be steered, controlled, and nudged to act in certain ways, or as sources of data which can be turned into products. In other words, smart citizens perform within the bounds of expected and acceptable behaviour, rather than transgressing or resisting social and political norms. Their involvement expresses a form of neoliberal citizenship not grounded in civil, social and political rights, or in the promotion of public or common good, but rather in individual autonomy. As such, claims concerning the production of "citizen-centric" smart cities appear to be largely tokenistic, with city administrations and corporations still owning and controlling urban governance and services, and smart city initiatives being used to enact a form of technologically-led entrepreneurial urbanism (Hollands 2008; Kitchin 2015; Swyngedouw 2016).

It seems to us that there is significant normative work to be done to rethink 'smart citizens' and 'smart citizenship'. Such normative thinking is beyond the aims and scope of this paper. However, it is interesting to note that beyond the academy some of this 
reconceptualization is already underway. For example, Barcelona is presently attempting to formulate and implement a different vision of a smart city and smart citizenship. Under a right-wing, neoliberal government, in the early 2010s Barcelona became the poster child for the smart city through its various initiatives and aggressive self-promotion, and the hosting of the Smart City Expo and World Congress (March and Ribera-Fumaz 2016). Since May 2015, however, with the election of a left-wing, green, social movement coalition, the city has transformed its vision of a smart city to one that is much more citizen-centric and grounded in notions of social and political citizenship. In the first year after taking office, the new city administration froze the issuing of new contracts for smart city initiatives and undertook an evaluation of existing ones. In mid-2016 a new Commissioner of Technology and Digital Innovation was appointed and a new selection of smart programs initiated. In October 2016 the city published 'Barcelona Ciutat Digital: A Roadmap Towards Technological Sovereignty'. ${ }^{15}$ Here, Barcelona as a smart city is re-envisioned as an "open, fair, circular and democratic city", with its mission "[to] solve city and citizens challenges through a more democratic use of technology" (March and Ribera-Fumaz 2017). Barcelona has thus sought to re-politicize the smart city and to shift its creation and control away from private interests and the state toward grassroots, civic movements and social innovation.

It remains to be seen whether the re-orientation under way in Barcelona will work in practice, or whether neoliberal models of smart citizenship prevalent previously and elsewhere will be reasserted. There appear to be few cities following Barcelona's new approach, despite the claims to being 'citizen-centric'. Certainly, Dublin is presently wedded to its existing neoliberal approach to smart city development (Coletta et al. 2017). Nonetheless, in our view, if smart cities are going to be populated by 'smart citizens' then city administrations should be seeking to shift as many of its initiatives as possible up the scaffold towards citizen engagement and citizen power. Ideally, this would also involve a reframing of paternalistic and market-driven notions of smart citizens towards one rooted in a form of citizenship

\footnotetext{
15 http://ajuntament.barcelona.cat/estrategiadigital/uploads/ BCN_Digital.pdf.
}

underpinned by rights and entitlements. The normative challenge then to creating truly 'citizen-centric' smart cities will be to re-imagine the political economy of cities and the role citizens are to play in their conception, development and governance.

Acknowledgements The research for this paper was provided by a European Research Council Advanced Investigator Award, 'The Programmable City' (ERC-2012-AdG-323636).

\section{Compliance with ethical standards}

Conflict of interest There are no conflicts of interest.

Ethical approval The research for this paper was passed for ethical approval by both the European Research Council and Maynooth University research ethics committees.

\section{References}

Arnstein, S. R. (1969). A ladder of citizen participation. Journal of the American Institute of Planners, 35(4), 216-224.

Breathnach, P. (2010). From spatial Keynesianism to postFordist neoliberalism: Emerging contradictions in the spatiality of the Irish State. Antipode, 42(5), 1180-1199.

Brenner, N., Peck, J., \& Theodore, N. (2010). Variegated neoliberalization: geographies, modalities, pathways. Global Networks, 10(2), 182-222.

Brenner, N., \& Theodore, N. (2002). Cities and the geographies of "actually existing neoliberalism". Antipode, 34(3), 349-379.

Cardullo, P., Kitchin, R., \& Di Feliciantonio, C. (2017). Living labs and vacancy in the neoliberal city. Cities. https://doi. org/10.1016/j.cities.2017.10.008.

Carpentier, N. (2016). Beyond the ladder of participation: An analytical toolkit for the critical analysis of participatory media processes. Javnost-The Public, 23(1), 70-88.

Clark, J., \& Shelton, T. (2016). Technocratic values and uneven development in the "Smart City." Metropolitics. Retrieved from http://www.metropolitiques.eu/Technocratic-Valuesand-Uneven.html.

Coletta, C., Heaphy, L., \& Kitchin, R. (2017). From accidental to articulated smart city: The creation and work of Smart Dublin. Programmable City Working Paper 29. Retrieved from https://osf.io/preprints/socarxiv/93ga5.

Coletta, C., \& Kitchin, R. (2017). Algorhythmic governance: Regulating the 'heartbeat' of a city using the Internet of Things. Big Data and Society, 4, 1-16.

Collins, K., \& Ison, R. (2009). Jumping off Arnstein's ladder: social learning as a new policy paradigm for climate change adaptation. Environmental Policy and Governance, 19(6), 358-373.

Cowley, R., Joss, S., \& Dayot, Y. (2017). The smart city and its publics: insights from across six UK cities. Urban Research and Practice, 1-25. https://doi.org/10.1080/ 17535069.2017.1293150. 
Crutcher, M., \& Zook, M. (2009). Placemarks and waterlines: Racialized cyberscapes in post-Katrina Google Earth. Geoforum, 40(4), 523-534.

Datta, A. (2015). New urban utopias of postcolonial India: "Entrepreneurial urbanization" in Dholera smart city, Gujarat. Dialogues in Human Geography, 5(1), 3-22.

de Lange, M., \& de Waal, M. (2013). Owning the city: New media and citizen engagement in urban design. First Monday, 18(11). Retrieved from http://firstmonday.org/ ojs/index.php/fm/article/view/4954.

de Waal, M. (2014). The city as interface: how digital media are changing the city. nai010 Rotterdam: Publishers.

Dodge, M., \& Kitchin, R. (2013). Crowdsourced cartography: Mapping experience and knowledge. Environment and Planning A, 45(1), 19-36.

Fuller, M. (2017). How to be a geek: Essays on the culture of software. Cambridge, UK; Malden, MA, USA: Polity

Gabrys, J. (2014). Programming environments: Environmentality and citizen sensing in the smart city. Environment and Planning D: Society and Space, 32(1), 30-48.

Greenfield, A. (2013). Against the smart city (1.3 edition). Berlin: Do projects.

Hart, R. A. (2008). Stepping back from 'the ladder': Reflections on a model of participatory work with children. In A. Reid, B. B. Jensen, J. Nikel, \& V. Simovska (Eds.), Participation and Learning (pp. 19-31). Netherlands, Dordrecht: Springer.

Heaphy, L., \& Pétercsák, R. (2016). Building smart city partnerships in the 'Silicon Docks', paper presented at the Creating Smart Cities workshop. Maynooth University, Ireland. Retrieved from http://bit.ly/2mjmyfd.

Hill, D. (2013). Essay: On the smart city; Or, a "manifesto" for smart citizens instead. Retrieved October 26, 2017, from http://www.cityofsound.com/blog/2013/02/on-the-smartcity-a-call-for-smart-citizens-instead.html.

Hollands, R. G. (2008). Will the real smart city please stand up? Intelligent, progressive or entrepreneurial? City, 12(3), 303-320.

Isin, E. F. (Ed.). (2000). Democracy, citizenship, and the global city. London; New York: Routledge.

Kitchin, R. (2014a). The data revolution: Big data, open data, data infrastructures and their consequences. London: SAGE Publications.

Kitchin, R. (2014b). The real-time city? Big data and smart urbanism. GeoJournal, 79(1), 1-14.

Kitchin, R. (2015). Making sense of smart cities: Addressing present shortcomings. Cambridge Journal of Regions, Economy and Society, 8(1), 131-136.

Kitchin, R. (2016). The ethics of smart cities and urban science. Philosophical Transactions of the Royal Society A, 374(2083), 1-20.

Kitchin, R., Coletta, C., Evans, L., Heaphy, L., \& Mac Donncha, D. (2017a). Smart cities, urban technocrats, epistemic communities, advocacy coalitions and the 'last mile' problem. it-Information Technology., 59(6), 275-284.

Kitchin, R., Coletta, C., \& McArdle, G. (2017b). Urban informatics, governmentality and the logics of urban control. Programmable City Working Paper 25. Retrieved from https://osf.io/preprints/socarxiv/27hz8/.

Kitchin, R., O'Callaghan, C., Boyle, M., Gleeson, J., \& Keaveney, K. (2012). Placing neoliberalism: The rise and fall of
Ireland's Celtic Tiger. Environment and Planning A, 44(6), 1302-1326.

Larner, W. (2003). Neoliberalism? Environment and Planning D: Society and Space, 21, 509-512.

Ljungberg, J. (2000). Open source movements as a model for organising. European Journal of Information Systems, 9(4), 208-216.

MacLaran, A., \& Kelly, S. (2014). Neoliberal urban policy and the transformation of the city: Reshaping Dublin. Berlin: Springer.

March, H., \& Ribera-Fumaz, R. (2016). Smart contradictions: The politics of making Barcelona a self-sufficient city. European Urban and Regional Studies, 23(4), 816-830.

March, H., \& Ribera-Fumaz, R. (2017). Against, for and beyond the smart city: Towards technological sovereignty in Barcelona. Boston: In Association of American Geographers conference.

McCann, B. (2014). A review of SCATS operation and deployment in Dublin. In Presented at the 19th JCT traffic signal symposium and exhibition. Retrieved from http://bit. ly/2pdLCs5.

McLaren, D., \& Agyeman, J. (2015). Sharing cities: A case for truly smart and sustainable cities. Cambridge: MIT Press.

Miller, H. J. (2010). The data avalanche is here. Shouldn't we be digging? Journal of Regional Science, 50(1), 181-201.

Ong, A. (2006). Mutations in citizenship. Theory, Culture and Society, 23(2-3), 499-505.

Perng, S.-Y. (2016). Creating infrastructure with citizens: Traffic light box artworks in Dublin streets, paper presented at the Creating Smart Cities workshop. Maynooth University, Ireland. Retrieved from http://bit.ly/2mjmyfd.

Perng, S.-Y., \& Kitchin, R. (2018). Solutions and frictions in civic hacking: collaboratively designing and building wait time predictions for an immigration office. Social and Cultural Geography, 19(1), 1-20.

Perng, S.-Y., Kitchin, R., \& Mac Donncha, D. (2017). Hackathons, entrepreneurship and the passionate making of smart cities. The Programmable City Working Paper 28. Retrieved from osf.io/nu3ec.

Sadowski, J., \& Pasquale, F. A. (2015). The spectrum of control: A social theory of the smart city. Retrieved from http:// firstmonday.org/ojs/index.php/fm/article/view/5903/ 4660 ? curator=TechREDEF.

Sartori, L. (2015). Alla ricerca della "smart citizenship". Istituzioni Del Federalismo: Rivista Di Studi Giuridici e Politici, 4, 927-948.

Seltzer, E., \& Mahmoudi, D. (2013). Citizen participation, open innovation, and crowdsourcing: Challenges and opportunities for planning. Journal of Planning Literature, 28(1), $3-18$.

Shelton, T., Zook, M., \& Wiig, A. (2015). The 'actually existing smart city'. Cambridge Journal of Regions, Economy and Society, 8(1), 13-25.

Swyngedouw, E. (2005). Governance innovation and the citizen: The Janus face of governance-beyond-the-State. $U r$ ban Studies, 42(11), 1991-2006.

Swyngedouw, E. (2016). The mirage of the sustainable 'smart' city. Planetary urbanization and the spectre of combined and uneven apocalypse. In O. Nel-lo \& R. Mele (Eds.), Cities in the 21st Century (pp. 134-143). London: Routledge. 
Tritter, J. Q., \& McCallum, A. (2006). The snakes and ladders of user involvement: Moving beyond Arnstein. Health Policy, 76(2), 156-168.

Vanolo, A. (2016). Is there anybody out there? The place and role of citizens in tomorrow's smart cities. Futures, 82, 26-36.
Wilcox, D. (1994). The Guide to Effective Participation. Retrieved from http://partnerships.org.uk/guide/AZpartic. html.

Wilson, W. J., \& Chaddha, A. (2009). The role of theory in ethnographic research. Ethnography, 10(4), 549-564. 